\title{
A CO-Tolerant Hydrogen Fuel Cell System Designed by Combining with an Extremely Active Pt/CNT Catalyst
}

\author{
Ken-ichi Tanaka $\cdot$ Masashi Shou $\cdot$ Hong He • \\ Changbin Zhang · Daling Lu
}

Received: 21 August 2008/Accepted: 10 September 2008/Published online: 2 October 2008

(C) Springer Science+Business Media, LLC 2008

\begin{abstract}
Complete oxidation of 2,000 ppm $\mathrm{CO}$ in $\mathrm{H}_{2}$ is attained over $10 \mathrm{wt} . \% \mathrm{Pt} / \mathrm{CNT}$ (carbon nano-tube) catalyst $(0.019 \mathrm{~g})$ at room temperature by adding $2,000 \mathrm{ppm} \mathrm{O}_{2}$ to hydrogen flowing at $100 \mathrm{~mL} / \mathrm{min}$. By insetting $5 \mathrm{wt} . \% \mathrm{Pt} /$ CNT catalyst $(0.8 \mathrm{~g})$ in front of a PEFC (polymer electrolyte hydrogen fuel cell), the PEFC generated maximum wattage of $0.45 \mathrm{~V} \times 0.75 \mathrm{~A} / \mathrm{cm}^{2}$ with no suppression for more than $7 \mathrm{~h}$ in a flow of $\mathrm{H}_{2}(400 \mathrm{~mL} / \mathrm{min})$ containing $1,000 \mathrm{ppm} \mathrm{CO}$. This result suggests a possibility of the hydrogen fuel cell operating in the shift gas.
\end{abstract}

Keywords CO-tolerant hydrogen fuel cell .

Low temperature PROX catalyst - Pt/CNT catalyst .

Polymer electrolyte hydrogen fuel cell

\section{Introduction}

From a view of clean and efficient energy source, various types of fuel cell have been proposed [1,2], and working models using hydrogen or methanol are already in the market. However, one awkward problem is the poisoning of Pt-anode by a trace amount of $\mathrm{CO}$ [3]. To avoid the

K.-i. Tanaka $(\bowtie) \cdot$ M. Shou

Advanced Science Research Laboratory, Saitama Institute of

Technology, 1690 Fusaiji, Fukaya, Saitama 369-0293, Japan

e-mail:ktanaka@sit.ac.jp

H. He - C. Zhang

Research Center for Eco-Environmental Sciences, Chinese Academy of Sciences, P. O. Box 2871, 18 Shuangqing Road, Beijing 100085, People's Republic of China

D. Lu

Chemical Resources Laboratory, Tokyo Institute of Technology, 4259 Nagatsuta, Midori-ku, Yokohama 226-8503, Japan poisoning by $\mathrm{CO}$, the $\mathrm{CO}$ in hydrogen is removed by preferential oxidation $(\mathrm{PROX})$ reaction at $150-170{ }^{\circ} \mathrm{C}$ through a reactor. On the other hand, a lot of efforts has been paid to develop CO-tolerant Pt-based anode, but the tolerance is lower than $100 \mathrm{ppm} \mathrm{CO}$. For example, Pt-Ni/C was tolerant for $50 \mathrm{ppm}$ [4] and $\mathrm{Pt}-\mathrm{Ru}$ on a defect free carbon nano-tube was for $100 \mathrm{ppm} \mathrm{CO}$ [5]. If complete oxidation of $\mathrm{CO}$ in $\mathrm{H}_{2}$ is attained at room temperature, we need not the reactor for PROX reaction. That is, the $\mathrm{CO}$ in hydrogen can remove by a small amount of catalyst inset in front of the fuel cell, and the fuel cell will operate in hydrogen containing several thousands ppm of $\mathrm{CO}$.

To realize such a CO-tolerant PEFC system, highly active PROX catalyst at room temperature is indispensable. So far, several low temperature PROX catalysts were developed [6-10], but their activity, selectivity, stability and reproducibility, were not fulfill the performance for our aimed CO-tolerant hydrogen fuel cell system. Fortunately, we found extremely active new catalyst, which was prepared by supporting $\mathrm{Pt}$ on carbon nano-tube [11]. In this paper, our aimed CO-tolerant hydrogen fuel cell system was realized by using Pt/CNT catalyst, which operated in hydrogen containing 1,000 ppm CO for several hours.

\section{Experiment}

The support carbon (Carbon nano-tube from Microphase Co., Vulcan carbon, and graphite powder) was degassed for $2 \mathrm{~h}$ at room temperature, and then immersed in a nitric acid solution of calculated amount of $\mathrm{Pt}\left(\mathrm{NH}_{3}\right)_{2}\left(\mathrm{NO}_{2}\right)_{2}(5,10$, or 15 wt.\% in Pt). By stirring the carbon for more than $12 \mathrm{~h}$, and then dried at $40{ }^{\circ} \mathrm{C}$ in a flow of $\mathrm{N}_{2}$. A certain amount of catalyst mounted in a reactor was treated by flowing $\mathrm{H}_{2}$ at $200{ }^{\circ} \mathrm{C}$. Oxidation reaction of $\mathrm{CO}$ in $\mathrm{H}_{2}$ was performed 
in a flow reactor with an on-line gas chromatography. The complete oxidation of $\mathrm{CO}$ in $\mathrm{H}_{2}$ at room temperature was attained at a value of $\mathrm{O}_{2} / \mathrm{CO}=0.75$ by increasing the ratio of $\mathrm{O}_{2} / \mathrm{CO}$ from 0.5 to 1.0 . Complete oxidation of 2,000 ppm $\mathrm{CO}$ in $\mathrm{H}_{2}$ with 2,000 ppm $\mathrm{O}_{2}\left(\mathrm{O}_{2} / \mathrm{CO}=1\right)$ was also confirmed at room temperature over $0.19 \mathrm{~g}$ of $10 \mathrm{wt} . \%$ $\mathrm{Pt} / \mathrm{CNT}$ catalyst (the $\mathrm{Pt}$ in $10 \mathrm{wt} \% \mathrm{Pt} / \mathrm{C}$ is equivalent to that in 1.2 wt. $\% \mathrm{Pt}$ on $\mathrm{Al}_{2} \mathrm{O}_{3}$ ) by flowing $\mathrm{H}_{2}$ at $100 \mathrm{~mL} / \mathrm{min}$. The $\mathrm{CO}$ in effluent gas measured by an infrared (IR) cell with a $2 \mathrm{~m}$ light pass (detectable level is $0.2 \mathrm{ppm} \mathrm{CO}$ ) proved complete oxidation of $\mathrm{CO}$ at room temperature.

Anode of a half cell of PEFC was prepared by hot pressing commercial 35\% Pt/C (Tanaka Noble Metal Co.) with a Nafion 115 electrolyte film, and was operated at ca. $80{ }^{\circ} \mathrm{C}$. CO-tolerance of a PEFC system insetting $5 \mathrm{wt} \%$ $\mathrm{Pt} / \mathrm{CNT}$ catalyst $(0.8 \mathrm{~g})$ was monitored by output voltage at $0.75 \mathrm{~A} / \mathrm{cm}^{2}$, which gave a maximum wattage $(0.45 \mathrm{~V} \times$ with no $\mathrm{CO}$ ) in a flow of $\mathrm{H}_{2}$ containing $1,000 \mathrm{ppm}$ of $\mathrm{CO}$ and $2.5 \% \mathrm{O}_{2}$ at $400 \mathrm{~mL} / \mathrm{min}$.

\section{Results and Discussion}

In our previous paper [11], we developed an extremely active PROX catalyst, which was prepared by supporting $\mathrm{Pt}$ on a carbon nano-tube $(\mathrm{Pt} / \mathrm{CNT})$. Interesting fact is that Pt supported on graphite and Vulcan carbon (used for anode) gives not so high activity as Pt/CNT. To realize the difference, performance of $15 \mathrm{wt} \% \mathrm{Pt} / \mathrm{CNT}$ catalyst (0.39 g), 15 wt.\% Pt/Vulcan-C (0.29 g), and 15 wt.\% Pt/ graphite $(0.30 \mathrm{~g})$ are referred in Fig. 1a. The conversion was obtained by flowing a mixture of $\mathrm{CO}(1.5 \mathrm{~mL} /$ $\min )+\mathrm{H}_{2}(15 \mathrm{~mL} / \mathrm{min})+\mathrm{O}_{2}(1.5 \mathrm{~mL} / \mathrm{min})+\mathrm{N}_{2}(38.5$ $\mathrm{mL} / \mathrm{min}$ ). It is clear that the activity of Pt/CNT catalyst is exceptionally high at room temperature. It is worthy of note that the activity of precious metal has so often discussed in relation with particle size, and the activity of $\mathrm{Au}$ particles is a typical case [12-14]. However, the particle size of $\mathrm{Pt}$ evaluated by XRD (not shown here) was 4.0-4.5 nm for Pt/CNT and 3.0-4.5 nm for Pt/Vulcan-C,
Fig. 1 a Conversion of $\mathrm{CO}$ (open) and $\mathrm{O}_{2}$ (solid) attained by flowing a mixture of $\{\mathrm{CO}(1.5 \mathrm{~mL} / \mathrm{min})+$ $\mathrm{O}_{2}(1.5 \mathrm{~mL} / \mathrm{min})+$ $\mathrm{H}_{2}(15.0 \mathrm{~mL} / \mathrm{min})+\mathrm{N}_{2} 38.5$ $(\mathrm{mL} / \mathrm{min})\}$ over $15 \mathrm{wt} . \%$ Pt/CNT $(0.39, \bigcirc \bullet), 15$ wt.\% $\mathrm{Pt} /$ graphite $(0.30 \mathrm{~g}, \triangle, \mathbf{\Lambda})$, and $15 \mathrm{wt} \% \mathrm{Pt} /$ Vulcan-C $(0.29 \mathrm{~g}, \square, \boldsymbol{\square}$,$) catalysts.$ b, c TEM images of the Pt/CNT and $\mathrm{Pt} /$ Vulcan-C catalysts
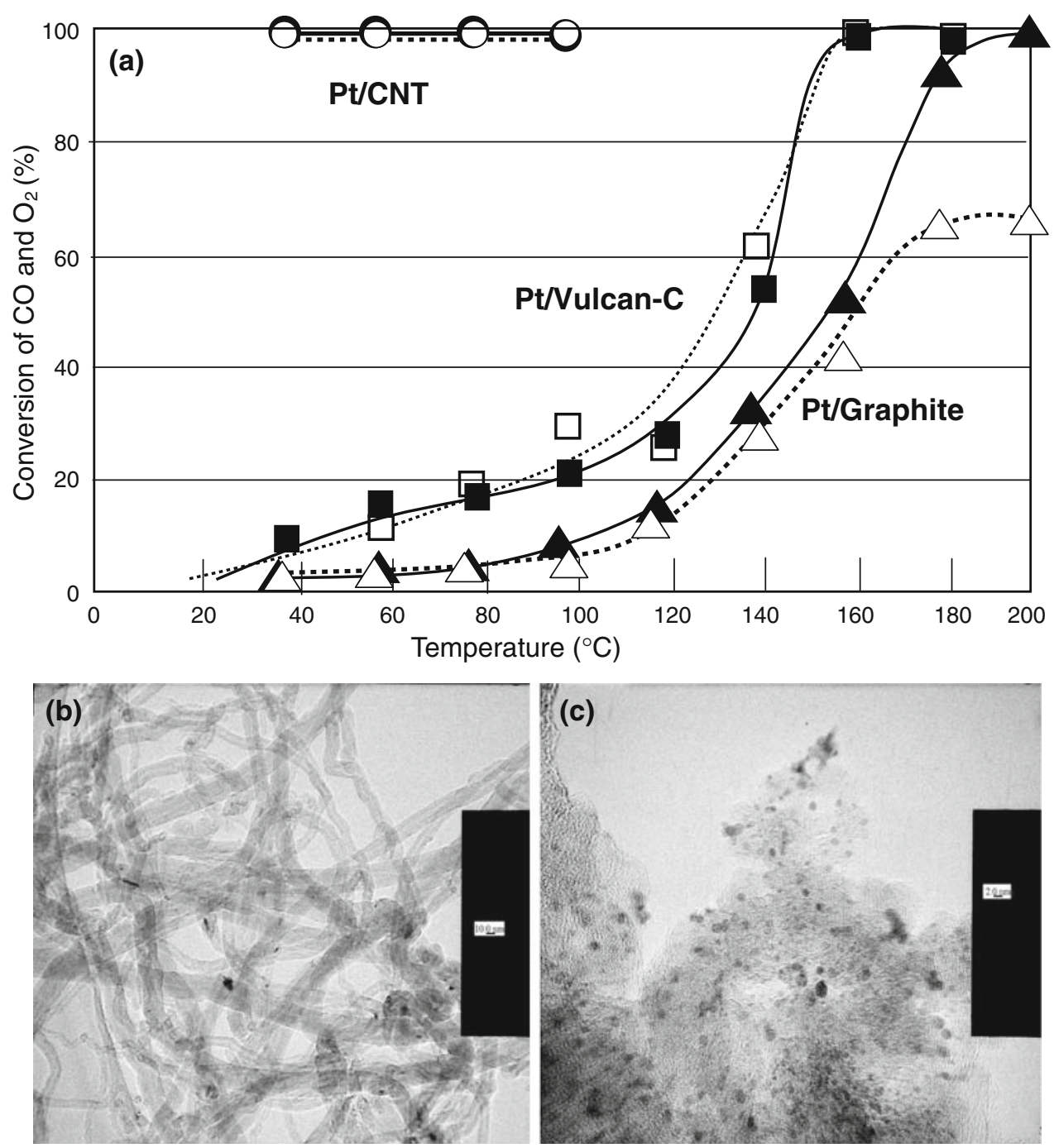
which were in good agreement with the size evaluated from the TEM image shown in Fig. $1 \mathrm{~b}$ and $\mathrm{c}$. Therefore, high activity of the Pt on carbon nano-tube is difficult to explain by particle size of Pt. In fact, large Pt particles on carbon nano-tube was far more active than that on the other carbon supports [11]. These facts reveal that physical meaning of the activity and the role of support are not so simple as have been explained by surface area or perimeter length of metal particles. Superior activity of $\mathrm{FeO}_{\mathrm{x}} / \mathrm{Pt} / \mathrm{TiO}_{2}$ prepared by loading a large amount of $\mathrm{FeO}_{\mathrm{x}}$ on a 1 wt. $\% \mathrm{Pt} / \mathrm{TiO}_{2}$ also reveals difficulty for the activity and the selectivity for the oxidation of $\mathrm{CO}$ in $\mathrm{H}_{2}$.

We have to remind that the activity depends on providing rate of reactant molecules to active sites or active component, but the providing is not always direct from gas phase but via diffusion over the support. Under these circumstances, the kinetics and the reaction rate is controlled by the rate determining step on the active component. In the case of selective oxidation of $\mathrm{CO}$ on the $\mathrm{FeO}_{\mathrm{x}} / \mathrm{Pt} / \mathrm{TiO}_{2}$ catalyst, oxidation of $\mathrm{CO}$ proceeds via $\mathrm{HCOO}^{-}$intermediate and the oxidation of $\mathrm{HCOO}$ with $\mathrm{OH}$ is the rate determining step [15]. This mechanism well explains the enhancement of the oxidation of $\mathrm{CO}$ by $\mathrm{H}_{2}$ and/or $\mathrm{H}_{2} \mathrm{O}$ and the hydrogen isotope effect by $\mathrm{H}_{2} / \mathrm{D}_{2}$ and $\mathrm{H}_{2} \mathrm{O} / \mathrm{D}_{2} \mathrm{O}$ [16]. Oxidation of $\mathrm{CO}$ on $\mathrm{Pt} / \mathrm{CNT}$ showed also hydrogen isotope effect by $\mathrm{H}_{2} / \mathrm{D}_{2}$ [Unpublished data], but the spectroscopic investigation of the $\mathrm{Pt} / \mathrm{CNT}$ catalyst is difficult.

The experiments on Pt/CNT were performed by flowing $\mathrm{H}_{2}$ containing rather high concentration of $\mathrm{CO}(\mathrm{CO} /$ $\mathrm{H}_{2}=0.10$ in Fig. 1). It was confirmed that the complete oxidation of $\mathrm{CO}$ in a flow of $\left(\mathrm{CO}(3.0 \mathrm{~mL} / \mathrm{min})+\mathrm{H}_{2}\right.$ $(20 \mathrm{~mL} / \mathrm{min})+\mathrm{O}_{2}+\mathrm{N}_{2}$ ) at $100 \mathrm{~mL} / \mathrm{min}$ on $5 \mathrm{wt} . \% \mathrm{Pt} /$ CNT $\left(0.8\right.$ g) at $35-40{ }^{\circ} \mathrm{C}$ was attained at $\mathrm{O}_{2} / \mathrm{CO}=0.75$ [11]. However, complete oxidation of several thousands ppm $\mathrm{CO}$ in $\mathrm{H}_{2}$ at room temperature should be certified to apply the Pt/CNT catalyst to PEFC. Figure 2 showed the oxidation of 2,000 ppm $\mathrm{CO}$ in $\mathrm{H}_{2}$ with $2,000 \mathrm{ppm} \mathrm{O}_{2}$ at room temperature by flowing at $100 \mathrm{~mL} / \mathrm{min}$ on $10 \mathrm{wt} . \%$ $\mathrm{Pt} / \mathrm{CNT}(0.19 \mathrm{~g})$ catalyst. Trace amount of $\mathrm{CO}$ in the effluent was detected by an IR-cell with $2 \mathrm{~m}$ light pass (detectable $0.2 \mathrm{ppm} \mathrm{CO}$ ), which proved the complete oxidation of $\mathrm{CO}$ for $20 \mathrm{~h}$.

Accordingly, the $\mathrm{CO}$ in $\mathrm{H}_{2}$ can remove through the $\mathrm{Pt} / \mathrm{CNT}$ catalyst inset in front of the PEFC by the oxidation with a certain amount of $\mathrm{O}_{2}$. The $\mathrm{I}-\mathrm{V}$ profile was measured by flowing $\mathrm{H}_{2}$ containing $2.5 \% \quad \mathrm{O}_{2}$ through a 5 wt.\% $\mathrm{Pt} / \mathrm{CNT}$ catalyst $(0.8 \mathrm{~g})$ at $400 \mathrm{~mL} / \mathrm{min} \quad(\mathrm{SV}=\mathrm{ca}$. $2,600 \mathrm{~h}^{-}$on the catalyst at room temperature) inset in front of the fumidifier of PEFC (ca. $80{ }^{\circ} \mathrm{C}$ ). The I-V profile was attained in a flow of $\mathrm{H}_{2}(400 \mathrm{~mL} / \mathrm{min})$ containing $2.5 \%$ of $\mathrm{O}_{2}$. The amount of $\mathrm{O}_{2}$ is ca. 10 times excess for several thousands ppm $\mathrm{CO}$, which is an unavoidable limit of our flow controlling system for the PEFC. Therefore, the PEFC

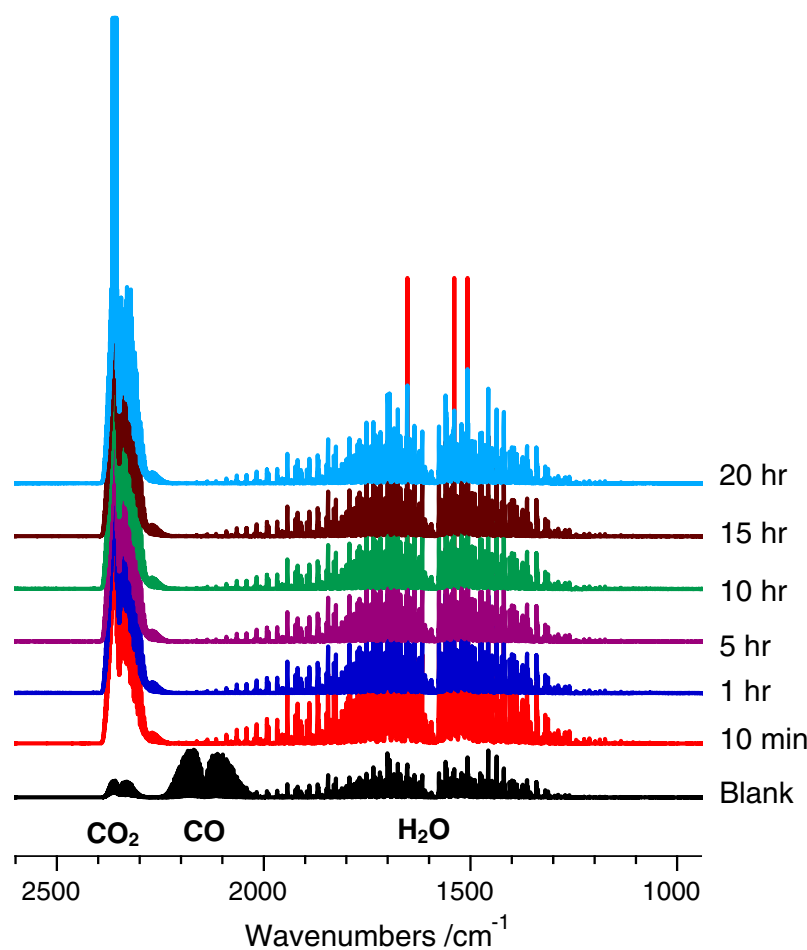

Fig. 2 I.R. spectrum of outlet gas proves complete oxidation of 2,000 ppm $\mathrm{CO}$ in $\mathrm{H}_{2}$ to $\mathrm{CO}_{2}$ with $2,000 \mathrm{ppm} \mathrm{O}_{2}$ over the $10 \%$ $\mathrm{Pt} / \mathrm{CNT}$ catalyst $(0.19 \mathrm{~g})$ at room temperature. Flow rate was 100 $\mathrm{mL} / \mathrm{min}$
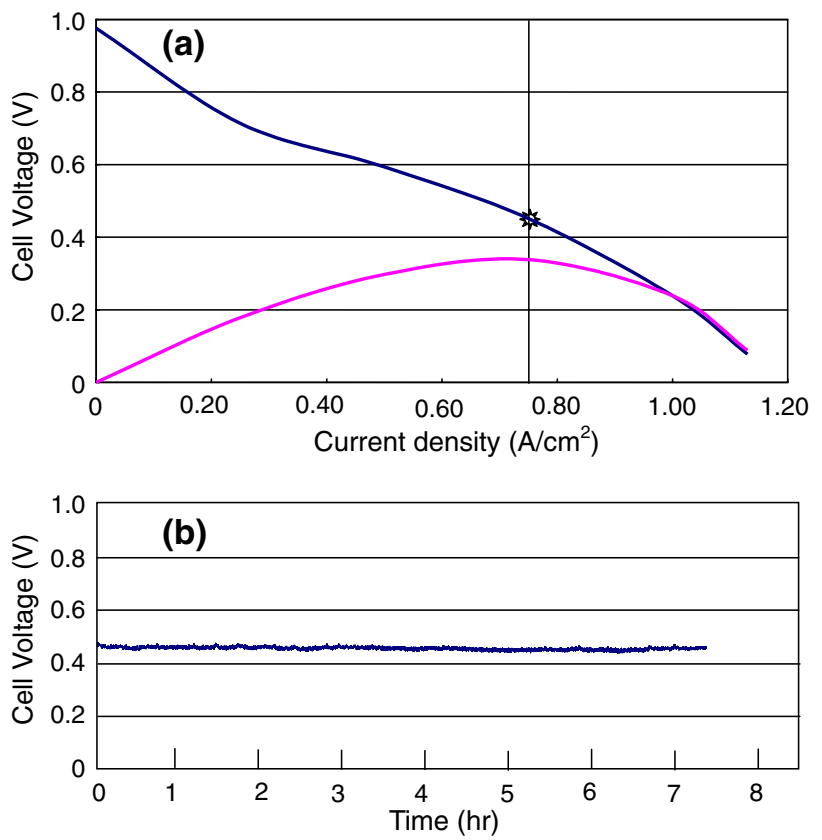

Fig. 3 a An $\mathrm{I}-\mathrm{V}$ curve of a half cell with an anode of $35 \% \mathrm{Pt} / \mathrm{C}$ attained by flowing $\mathrm{H}_{2}$ with $25,000 \mathrm{ppm} \mathrm{O}_{2}$ and no $\mathrm{CO}$ at 400 $\mathrm{mL} / \mathrm{min}$. b Performance of the PEFC setting $5 \mathrm{wt}$.\% Pt/CNT catalyst $(0.8 \mathrm{~g})$. A steady output voltage at $0.75 \mathrm{~A}$ was monitored by flowing $\mathrm{H}_{2}$ containing $1,000 \mathrm{ppm} \mathrm{CO}$ and $25,000 \mathrm{ppm} \mathrm{O}_{2}$ through at 400 $\mathrm{mL} / \mathrm{min}\left(\mathrm{SV}=2,600 \mathrm{~h}^{-}\right)$ 
may lose ca. $4 \%$ of output power by reacting $\mathrm{H}_{2}$ with $\mathrm{O}_{2}$, but it is not an important problem for our purpose because $\mathrm{O}_{2}$ gives no influence on the $\mathrm{I}-\mathrm{V}$ profile as the blank $\mathrm{I}-\mathrm{V}$ profile with no $\mathrm{CO}$ shows in Fig. 3a. The maximum wattage of the PEFC attained in the blank I-V profile was $0.75 \mathrm{~A} / \mathrm{cm}^{2} \times 0.45 \mathrm{~V}$. If the Pt-anode of PEFC will be poisoned by $\mathrm{CO}$, the output voltage at $0.75 \mathrm{~A} / \mathrm{cm}^{2}$ is sensitively suppressed. After the blank test of the PEFC, about $1,000 \mathrm{ppm}$ of $\mathrm{CO}$ was added to $\mathrm{H}_{2}$ flow, and the output voltage at $0.75 \mathrm{~A} / \mathrm{cm}^{2}$ was monitored with time. As shown in Fig. 3b, the output voltage at $0.75 \mathrm{~A} / \mathrm{cm}^{2}$ took no suppression in $\mathrm{H}_{2}$ containing $1,000 \mathrm{ppm}$ of $\mathrm{CO}$, that is, the PEFC system is tolerant for $1,000 \mathrm{ppm} \mathrm{CO}$. We could conclude that development of CO-tolerant anode for several thousands ppm CO is impractical, but the development of hydrogen fuel cell system being tolerant for $\mathrm{CO}$ of several thousands ppm is practical as demonstrated in this paper. Taking these results into account, we conclude that developing of active PROX catalyst such as Pt/CNT will make realize the PEFC system operating in the shift gas.

Acknowledgement One of the authors, K. Tanaka, appreciates Mr. Mitsushi Umino of Astech Co. for his warm support of our research work, and to Kawaken fine chemicals Co. for a part of financial support.

\section{References}

1. Hibini T, Hshimoto A, Inoue T, Tokuno J, Yoshida S, Sano M (2000) Science 288:2031

2. Kim WB, Voitl T, Rodoriguez-Rivera J, Dumesic DA (2004) Science 305:1280

3. Ralph TR, Hogarth MP (2002) Ptatinum Metal Rev 46:117

4. Okada T, Yano H, Ono C (2007) J New Mater Electrochem Syst 10:129

5. Yoo E, Okada T, Kizuka T, Nakamura J (2007) Electrochemistry $75: 146$

6. Tanaka K, Moro-oka Y, Ishigure K, Yajima T, Okabe Y, Kato Y, Hamano H, Sekiya S, Tanaka H, Matsumoto Y, Koinuma H, He H, Zhang C, Feng Q (2004) Catal Lett 92:115

7. Shi X, Zhang C, Shou M, He H, Sugihara S, Tanaka K (2006) Catal Lett 107:1

8. Landon P, Forguson J, Solsona BE, Garcia T, Carley AF, Herzing AA, Kiely CJ, Golunski SE, Hutchings GJ (2005) Chem Comm 3385

9. Okumur M, Nakamura S, Tsubota S, Nakamura T, Azuma M, Haruta M (1998) Catal Lett 52:53

10. Tanaka K, Shou M, He H, Shi X (2006) Catal Lett 110:185

11. Tanaka K, Shou M, Zhang H, Yuan Y, Hagiwara T, Fukuoka A, Nakamura J, Lu D (2008) Catal Lett 124 (in press)

12. Haruta M (1997) Catal Today 36:153

13. Valden M, Lai X, Goodman DW (1998) Science 281:1647

14. Shou M, Takekawa H, Ju D-Y, Hagiwara T, Tanaka K (2006) Catal Lett 108:119

15. Tanaka K, Shou M, Shi X, He H (2008) Catal Lett 120:210

16. Shou M, Tanaka K (2006) Catal Lett 111:115 